\title{
Exacerbated inflammatory cellular immune response characteristics of HAM/TSP is observed in a large proportion of HTLV-I asymptomatic carriers
}

\author{
Silvane Braga Santos ${ }^{1}$, Aurélia Fonseca Porto ${ }^{1}$, André Luiz Muniz ${ }^{1}$ \\ Amélia Ribeiro de Jesus ${ }^{1}$, Elza Magalhães ${ }^{2}$, Ailton Melo ${ }^{2}$, Walderez O Dutra ${ }^{3}$, \\ Kenneth J Gollob ${ }^{4}$ and Edgar M Carvalho*1,5
}

\begin{abstract}
Address: ${ }^{1}$ Serviço de Imunologia, Hospital Universitário Professor Edgard Santos (HUPES), Universidade Federal da Bahia (UFBA), Salvador, Bahia, Brasil, ${ }^{2}$ Serviço de Neurologia, HUPES, UFBA, Salvador, Bahia, Brasil, ${ }^{3}$ Departamento de Morfologia, Instituto de Ciências Biológicas (ICB), Universidade Federal de Minas Gerais (UFMG), Belo Horizonte, Minas Gerais, Brasil, ${ }^{4}$ Departamento de Bioquímica e Imunologia, ICB, UFMG, Belo Horizonte, Minas Gerais, Brasil and ${ }^{5}$ Instituto de Investigação em Imunologia, São Paulo, Brasil

Email: Silvane Braga Santos - silvane@ufba.br; Aurélia Fonseca Porto - porto@ufba.br; André Luiz Muniz - muniz.a@terra.com.br; Amélia Ribeiro de Jesus - amelia@ufba.br; Elza Magalhães - imuno@ufba.br; Ailton Melo - imuno@ufba.br;

Walderez O Dutra - waldutra@mono.icb.ufmg.br; Kenneth J Gollob - kjgollob@terra.com.br; Edgar M Carvalho* - edgar@ufba.br

* Corresponding author
\end{abstract}

Published: 02 March 2004

BMC Infectious Diseases 2004, 4:7
Received: 07 October 2003

Accepted: 02 March 2004

This article is available from: http://www.biomedcentral.com/I47I-2334/4/7

(c) 2004 Santos et al; licensee BioMed Central Ltd. This is an Open Access article: verbatim copying and redistribution of this article are permitted in all media for any purpose, provided this notice is preserved along with the article's original URL.

\begin{abstract}
Background: A small fraction of Human T cell Leukemia Virus type-I (HTLV-I) infected subjects develop a severe form of myelopathy. It has been established that patients with HTLV-I associated myelopathy/tropical spastic paraparesis (HAM/TSP) show an exaggerated immune response when compared with the immunological response observed in HTLV-I asymptomatic carriers. In this study the immunological responses in HAM/TSP patients and in HTLV-I asymptomatic carriers were compared using several immunological assays to identify immunological markers associated with progression from infection to disease.
\end{abstract}

Methods: Immunoproliferation assays, cytokine levels of unstimulated cultures, and flow cytometry analysis were used to evaluate the studied groups. Nonparametric tests (Mann-Whitney $U$ test and Wilcoxon matched-pairs signed ranks) were used to compare the difference between the groups.

Results: Although both groups showed great variability, HAM/TSP patients had higher spontaneous lymphoproliferation as well as higher IFN- $\gamma$ levels in unstimulated supernatants when compared with asymptomatic carriers. Flow cytometry studies demonstrated a high frequency of inflammatory cytokine (IFN- $\gamma$ and TNF- $\alpha$ ) producing lymphocytes in HAM/TSP as compared to the asymptomatic group. This difference was accounted for mainly by an increase in CD 8 cell production of these cytokines. Moreover, the HAM/TSP patients also expressed an increased frequency of CD28-/CD8+ T cells. Since forty percent of the asymptomatic carriers had spontaneous lymphoproliferation and IFN- $\gamma$ production similar to HAM/TSP patients, IFN- $\gamma$ levels were measured eight months after the first evaluation in some of these patients to observe if this was a transient or a persistent situation. No significant difference was observed between the means of IFN- $\gamma$ levels in the first and second evaluation.

Conclusions: The finding that a large proportion of HTLV-I carriers present similar immunological responses to those observed in HAM/TSP, strongly argues for further studies to evaluate these parameters as markers of HAM/TSP progression. 


\section{Background}

Human T cell leukemia virus-type 1 (HTLV-I) infects an estimated 10 to 20 million people worldwide, making it a serious public healthy problem. The HTLV-1 infection has a high prevalence in Brazil, and Salvador, the capital of the state of Bahia, has the highest prevalence of HTLV-1 in the country in blood donors $(1,35 \%)[1,2]$. It is estimated that $95 \%$ of HTLV-I infected individuals are asymptomatic carriers. A small percentage of infected individuals ( 2 to $5 \%$ ) develop adult T cell leukemia/lymphoma (ATL) $[3,4]$ or a chronic inflammatory disease, involving the central nervous system, termed HTLV-I associated myelopathy/tropical spastic paraparesis (HAM/TSP) $[5,6]$. One of the most important immunological observations of HTLV-I infection is the demonstration that lymphocytes spontaneously proliferate in vitro in the absence of stimulus [7]. It has been shown that both infected CD4+ and CD8+ lymphocytes infiltrate spinal cord and peripheral blood and produce cytokines such IFN- $\gamma$, TNF$\alpha$ and IL- 6 , which are considered important inflammatory mediators of the tissue damage in HAM/TSP [8-10]. Extensive previous studies have compared the immunological response of asymptomatic HTLV-I carriers to that of HAM/TSP patients $[11,12]$. Additionally, a recent study [13] has emphasized that the percentage of HTLV-I carriers that develop other immunological abnormalities, including HAM/TSP, is much higher than that previously cited in the literature. The aim of the present study is to compare in HTLV-I asymptomatic carriers, and in HAM/ TSP patients, the spontaneous lymphoproliferative response and cytokine production, the overall ex vivo $\mathrm{T}$ cell activation states, and the production of immunoregulatory cytokines by CD4+ and CD8+ T cells. The documentation that some HTLV-I carriers have immunological alteration similar to that observed in HAM/TSP suggests that potential markers of disease progression may be determined in HTLV-I infection.

\section{Methods}

\section{Patients selection and neurological exam}

Patients were selected from the HTLV-I clinic of the Hospital Universitário Professor Edgard Santos, Federal University of Bahia, Brazil. The diagnosis was confirmed by Western blot (HTLV blot 2.4, Genelabs, Singapore). Seventeen patients with HAM/TSP were selected based on WHO criteria and thirty-six HTLV-I asymptomatic carriers were referred from two blood banks. Exclusion criteria included the use of antiviral drugs or immunomodulators in the previous 90 days, helminth infection, co-infection with HIV, HCV or hepatitis B and presence of other neurologic diseases. Motor dysfunction was determined by Osame's Motor Disability Score (OMDS) [14] and Expanded Disability Status Scale (EDSS) [15]. Patients with HAM/TSP had a marked neurological impairment with EDSS $\geq 3$ and OMDS $\geq 1$ and all asymptomatic sub- jects had OMDS and EDSS of zero. Seronegative normal donors were also referred from the same blood banks and used as negative controls. The Ethical Committee of the Hospital Universitário Professor Edgard Santos approved this study and informed consent was obtained from all prospectively enrolled patients.

\section{Cell preparation and proliferation assay}

Peripheral blood mononuclear cells (PBMC) were isolated and cultivated in RPMI 1640 (Gibco, Grand Island, NY, USA) plus $10 \%$ heat inactivated human $\mathrm{AB}$ Rh+ serum (Sigma Chemical Co., St. Louis, MO), antibiotics and glutamine. A total of $2 \times 10^{5}$ cells $/ \mathrm{mL}$ were incubated at $37^{\circ} \mathrm{C}$ in $5 \% \mathrm{CO}_{2}$ atmosphere in a 96 well flat-bottom microtiter plates. The cells were kept unstimulated (media alone) and after 5 days, the cultures were pulsed with ${ }^{3} \mathrm{H}$ Thymidine $(1 \mu \mathrm{Ci} /$ well $)$ for a final $6-16$ hours period, and then harvested. The ${ }^{3} \mathrm{H}$-Thymidine uptake was measured using a LKB beta scintillation counter. The average of counts per minute $(\mathrm{cpm})$ was plotted and PHA $(1.0 \mu \mathrm{g} /$ $\mathrm{mL}$, Sigma) was used as a positive control in the proliferation assay.

\section{Cytokine determination}

PBMC were adjusted to $3 \times 10^{6}$ cells/mL in RPMI 1640 plus $10 \%$ serum AB Rh+. The cells were cultured unstimulated or stimulated with PHA $(5 \mu \mathrm{g} / \mathrm{mL})$ and all cultures were incubated at $37^{\circ} \mathrm{C}$ in $5 \% \mathrm{CO}_{2}$ atmosphere for 72 hours until supernatants were collected. IFN- $\gamma$, TNF- $\alpha$, IL5 and IL-10 levels were measured by sandwich ELISA technique ( $\mathrm{R} \& \mathrm{D}$ system, Minneapolis, $\mathrm{MN}$ ).

\section{Ex vivo staining of lymphocyte profiles}

$2 \times 10^{5}$ PBMC from HTLV-I patients were incubated with FITC, PE, or Cychrome-labeled antibody solutions for 20 minutes at $4{ }^{\circ} \mathrm{C}$. After staining, preparations were washed with $0.1 \%$ sodium-azide PBS, fixed with $2 \%$ formaldehyde in PBS and kept at $4^{\circ} \mathrm{C}$ until data acquisition using a FACScalibor (Becton Dickinson, San Jose, CA). The antibodies used were all directly conjugated either for FITC, PE, or Cychrome and consisted of: Ig controls, antiCD4, CD8, CD28, CD69 (Pharmingen, San Diego, CA) and anti-CD62L (Caltag, Burlingame, CA).

\section{Single cell cytoplasmic cytokine staining}

Briefly, $2 \times 10^{5}$ PBMC were cultured in RPMI 1640 plus $5 \% \mathrm{AB} \mathrm{Rh}+$ serum in 96 well plates. Based on preliminary results all the cytokine staining was performed after 20 hours of incubation. During the last 4 hours of culture, Brefeldin-A $(1 \mu \mathrm{g} / \mathrm{mL})$ was added to the culture. The cells were then washed and centrifuged using ice-cold PBS plus sodium-azide, stained for surface markers and fixed using $2 \%$ formaldehyde. The fixed cells were then permeablized with a solution of Saponin and stained, for 30 minutes at $4^{\circ} \mathrm{C}$, using anti-cytokine mAbs directly conjugated with 
PE (IFN- $\gamma$, TNF- $\alpha$, IL-4 and IL-10) (Pharmingen). Preparations were then washed, fixed and analyzed using a FACScalibor. In all cases the cells were double stained for cytokine and for cell surface markers. In all cases, 30,000 gated events were acquired for later analysis due to the low frequency of positive events being analyzed.

\section{Statistical analysis}

A nonparametric Mann-Whitney $U$ test and Wilcoxon matched-pairs signed rank tests were used to evaluate differences between the groups. An alpha $(\alpha)$ of $5 \%(p<$ $0.05)$ was considered for statistical significance. Lymphocytes were analyzed for their intracellular cytokine expression patterns and frequencies and for surface markers using the program Cell Quest. Statistical analysis was performed using the ANOVA "comparison of all pairs" contained in the statistical program from SAS, JMP.

\section{Results}

The mean age of the seventeen myelopathy patients was $53 \pm 16$ (mean \pm SD) years and of the thirty-six HTLV-I healthy carriers was $39 \pm 11$ years. To determine if HAM/ TSP patients and asymptomatic subjects produce different levels of secreted cytokines, IFN- $\gamma$, TNF- $\alpha$, IL-10 and IL- 5 were measured in supernatants of unstimulated cultures of HTLV-I infected groups and compared with negative controls. There was a high variability in IFN- $\gamma$ levels in asymptomatic carriers (Figure 1A). The mean and SD of IFN- $\gamma$ levels in myelopathy patients $(4,246 \pm 2,924 \mathrm{pg} /$ $\mathrm{mL}$, range: 375 to 10,750$)$, was higher than that observed in asymptomatic carriers $(1,362 \pm 1,408 \mathrm{pg} / \mathrm{mL}$ range: 15 to 6,995$)$ or in negative controls $(1 \pm 4 \mathrm{pg} / \mathrm{mL}), p=$ 0.0001, Mann-Whitney U test. There was also a tendency for higher TNF- $\alpha$ levels in HAM/TSP patients $(378 \pm 316$ $\mathrm{pg} / \mathrm{mL}$ ) when compared with levels observed in asymptomatic carriers $(259 \pm 366 \mathrm{pg} / \mathrm{mL})$ or in negative controls $(60 \pm 63 \mathrm{pg} / \mathrm{mL}), p=0.06$. No differences between IL-5 levels $(151 \pm 141$ versus $166 \pm 231 \mathrm{pg} / \mathrm{mL}), p=0.17$ and IL-10 levels $(70 \pm 66$ versus $94 \pm 110 \mathrm{pg} / \mathrm{mL}), p=0.9$, were observed between HTLV-I infected groups or negative controls $(2 \pm 2$ versus $2.6 \pm 10$ ), Figure $1 \mathrm{~B}$.

The lymphoproliferative assays performed using PBMC from ten HAM/TSP patients and eleven asymptomatic individuals showed that lymphoproliferation was higher in HAM/TSP than HTLV-I asymptomatic carriers. The five day spontaneous proliferation of the HAM/TSP group gave a mean and SD of 21,404 $\pm 30,859 \mathrm{cpm}$ (range: 919 to 102,242$)$, while the asymptomatic HTLV-I group had a mean and SD of $3,365 \pm 5,188 \mathrm{cpm}$ (range: 139 to $18,169)$. The magnitude of the responses was higher in HAM/TSP than in HTLV-I carriers $(\mathrm{p}=0.006)$ although a great variability of the spontaneous lymphoproliferation had been observed in both groups (date not shown).
Based on IFN- $\gamma$ production, the immunological responses in $40 \%$ of the HTLV-I carriers were similar to that observed in patients with HAM/TSP ( $\mathrm{p}>0.05)$. These individuals had IFN- $\gamma$ levels higher than $1,322 \mathrm{pg} / \mathrm{mL}$, representing the mean minus one standard deviation of the IFN- $\gamma$ levels obtained in HAM/TSP patients. To determine if the cytokine levels in HTLV-I carriers was reflecting a transient or persistent situation, IFN- $\gamma$ levels were measured between 6 months to one year (with a mean of eight months) after the first evaluation. No significant differences were observed between the means of IFN- $\gamma$ levels from fourteen asymptomatic carriers in the first and second evaluation $(1,723 \pm 450$ and $1,670 \pm 1,396$, respectively), $\mathrm{p}=0.67$. HAM/TSP patients $(\mathrm{n}=11)$ also had similar levels in the first and second evaluation $(5,771 \pm$ 3,365 versus $4,718 \pm 2,427$, respectively), $\mathrm{p}=0.17$, Wilcoxon matched-pairs signed ranks test (Figure 2).

To determine the activation states and relative lymphocyte proportions, as well as the cellular sources of immunoregulatory cytokines, four HAM/TSP patients and eight asymptomatic carriers were randomly selected and analyzed using flow cytometry. To measure lymphocyte activation and regulation, the markers CD69 and CD28 respectively, where used in conjunction with CD4 and CD8 in separate staining protocols. The relative proportions of CD4 and CD8 cells expressing the adhesion molecule, CD62L was also determined for both groups. Figure $3 \mathrm{~A}$ demonstrates that the HAM/TSP group expressed a significantly higher frequency of CD8+ T cells $(21.4 \pm 3.3)$ than the asymptomatic group $(9.8 \pm 1.7)$. A higher frequency $(51.9 \pm 3.5)$ of the hyper-activated, CD28-/CD8+ $\mathrm{T}$ cells within the CD8+ $\mathrm{T}$ cell population in HAM/TSP than in asymptomatic group (35.2 \pm 7.4$)$ was also observed. There was no difference in CD69 and CD62L lymphocyte populations between both HTLV-I infected groups (data not shown).

To further investigate the differences in cytokine profile between the HAM/TSP and asymptomatic groups, flow cytometry was performed to determine the frequency of $\mathrm{T}$ cells producing IFN- $\gamma$, TNF- $\alpha$, IL-4 and IL-10. A significant increase in the frequency of lymphocytes expressing TNF$\alpha$ and IFN- $\gamma$ was seen in the HAM/TSP group (12 \pm 6 and $5 \pm 0.3$, respectively) as compared to the asymptomatic group ( $4 \pm 2$ and $1 \pm 0.5$, respectively) (Figure $3 \mathrm{~B}$ ). Moreover, CD8+ T cells where the major cellular source responsible for the difference in IFN- $\gamma$ producing cells between the two groups. The frequency of CD8+ T cells producing TNF- $\alpha$ was higher in HAM/TSP as compared to asymptomatic carriers, with both CD4+ and CD8+ T cells contributing equally to the difference seen in TNF- $\alpha$ production (Figure 3C). In contrast, no difference was seen for the frequency of cells producing IL-4 or IL-10 (data not shown). While there was no difference regarding the frequency of 


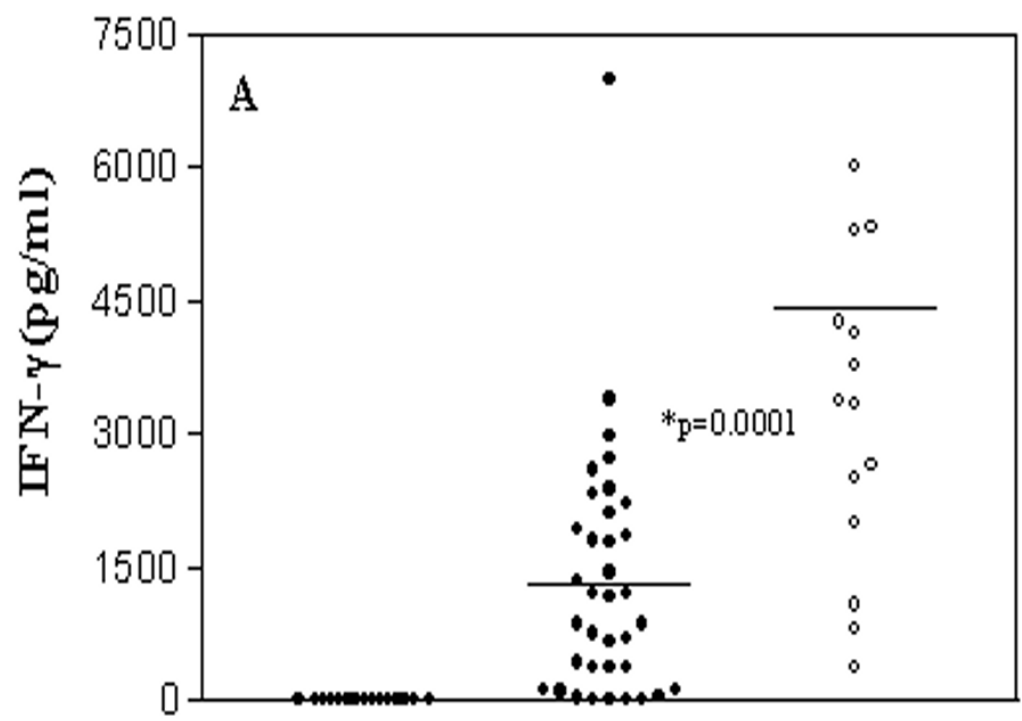

\section{Negative Asymptomatic Myelopathy controls}

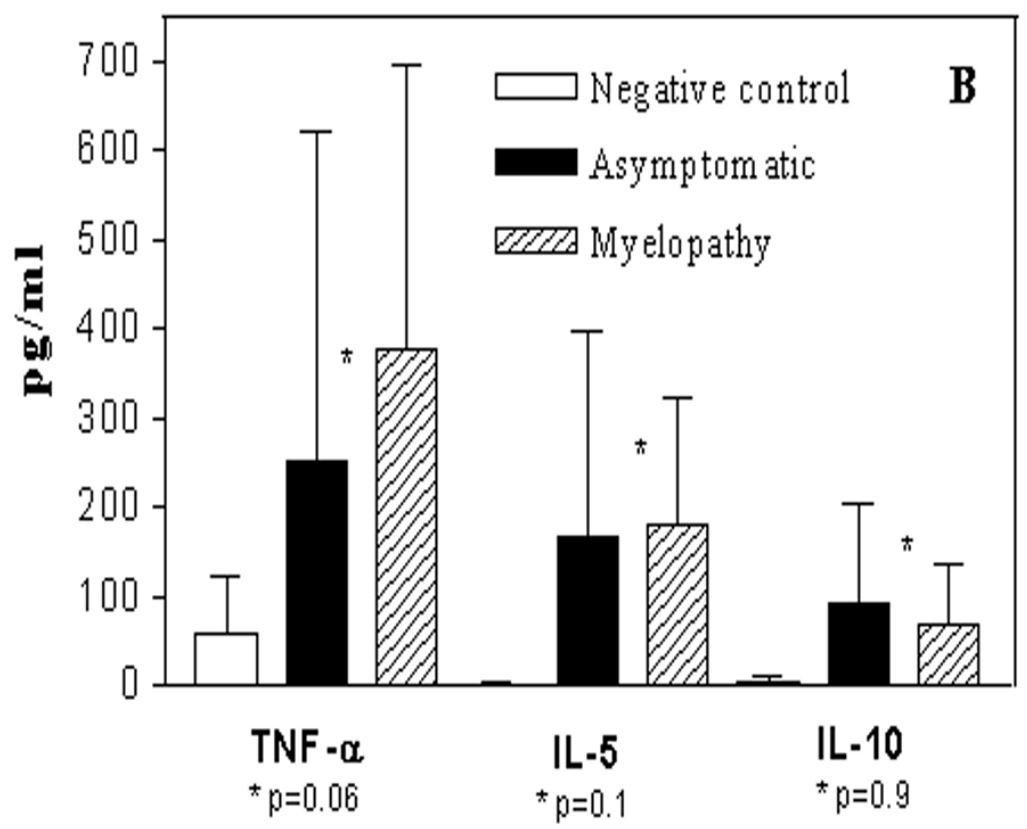

\section{Figure I}

HAM/TSP patients display higher production of IFN- $\gamma$ as compared with others cytokines synthesis. Unstimulated cultures supernatants of PBMC from 17 HAM/TSP patients and 36 asymptomatic carriers were compared with negative controls $(n=15)$ and assayed by ELISA to observe IFN- $\gamma$, TNF- $\alpha$, IL- 5 and IL- I0 synthesis. Figure IA shows IFN- $\gamma$ levels (pg/ml) in HAM/TSP patients as compared with asymptomatic carries or negative controls. Figure IB shows TNF- $\alpha$, IL- 5 and IL- 10 levels in both groups. The bars represent the median of IFN- $\gamma$ concentrations and the difference were considered significant when $p<0.05$ (Mann-Whitney U Test). 

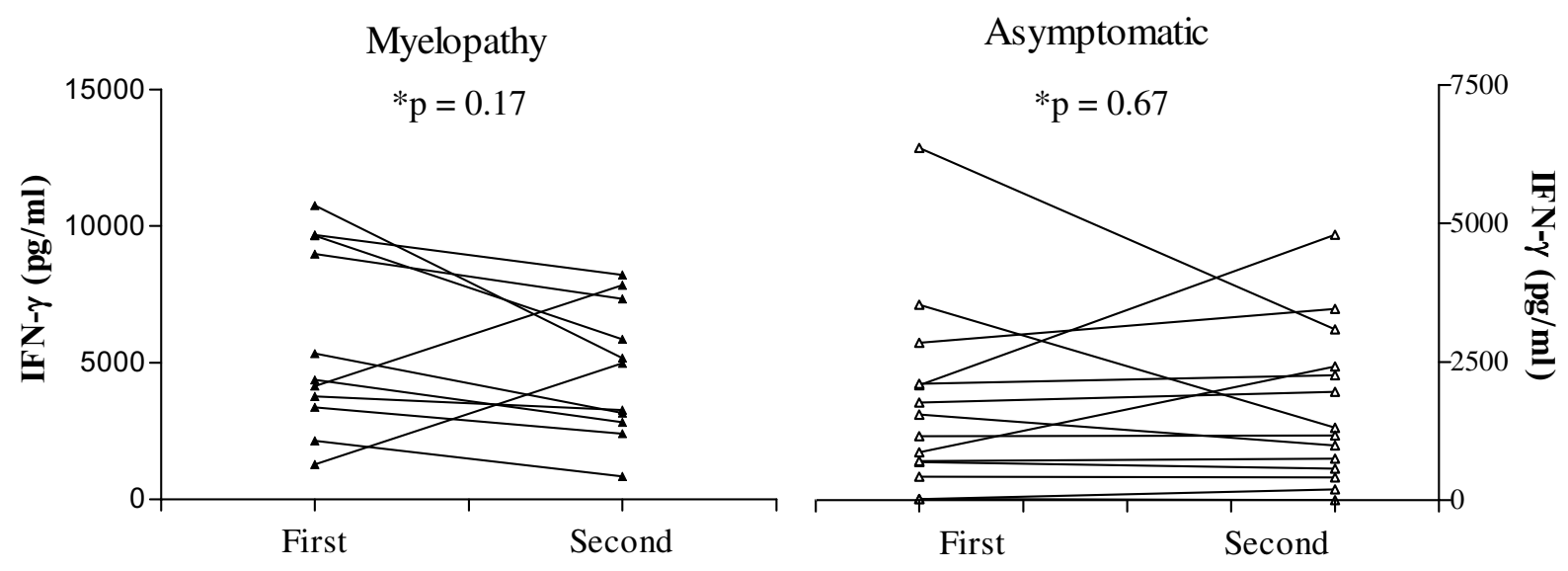

\section{Figure 2}

IFN- $\gamma$ levels are relatively constant when evaluated in two different periods. Unstimulated cultures supernatants of PBMC from II HAM/TSP patients and I 4 asymptomatic carriers were assayed by ELISA and analyzed at the initial evaluation and eight months following the first evaluation. The data represent IFN- $\gamma$ levels $(\mathrm{pg} / \mathrm{ml})$ of each patient in first and second evaluation. The differences were not statistically significant ( $p>0.05$, Wilcoxon matched-pairs signed ranks test).

CD4+ and CD8+ T cells producing IFN- $\gamma$ within asymptomatic carriers $(0.5 \pm 0.4$ vs. $0.5 \pm 0.3)$, there was a significant difference $(\mathrm{p}<0.05)$ in the frequency of CD4 cells producing IFN- $\gamma$ in HAM/TSP $(1.4 \pm 0.5)$ compared to the CD8+ T cells $(3.6 \pm 0.5)$.

\section{Discussion}

The present study shows that lymphocytes from patients with HAM/TSP displayed higher spontaneous proliferation and IFN- $\gamma$ synthesis, a higher frequency of TNF- $\alpha$ and IFN- $\gamma$ producing lymphocytes and a significant increase in the deregulated T cell population, CD28-/CD8+, as compared to those from HTLV-I asymptomatic carriers.
The pathogenesis of HAM/TSP is not completely understood. Although initially considered a rare and late complication of infection, the disease has been identified in children, and in some cases, a rapidly progressive disease has been observed [16]. Increased proviral load, proinflammatory cytokines and the expansion of HTLV-I taxspecific CD8+ cytotoxic T lymphocytes, both in cerebrospinal fluid and in peripheral blood, have been associated with the central nervous system involvement in patients with HAM/TSP [17-21]. A recent report [13] established a cohort of HTLV-I asymptomatic carries to study clinical events and documented an increased frequency of abnormalities, including a case of HAM/TSP. 

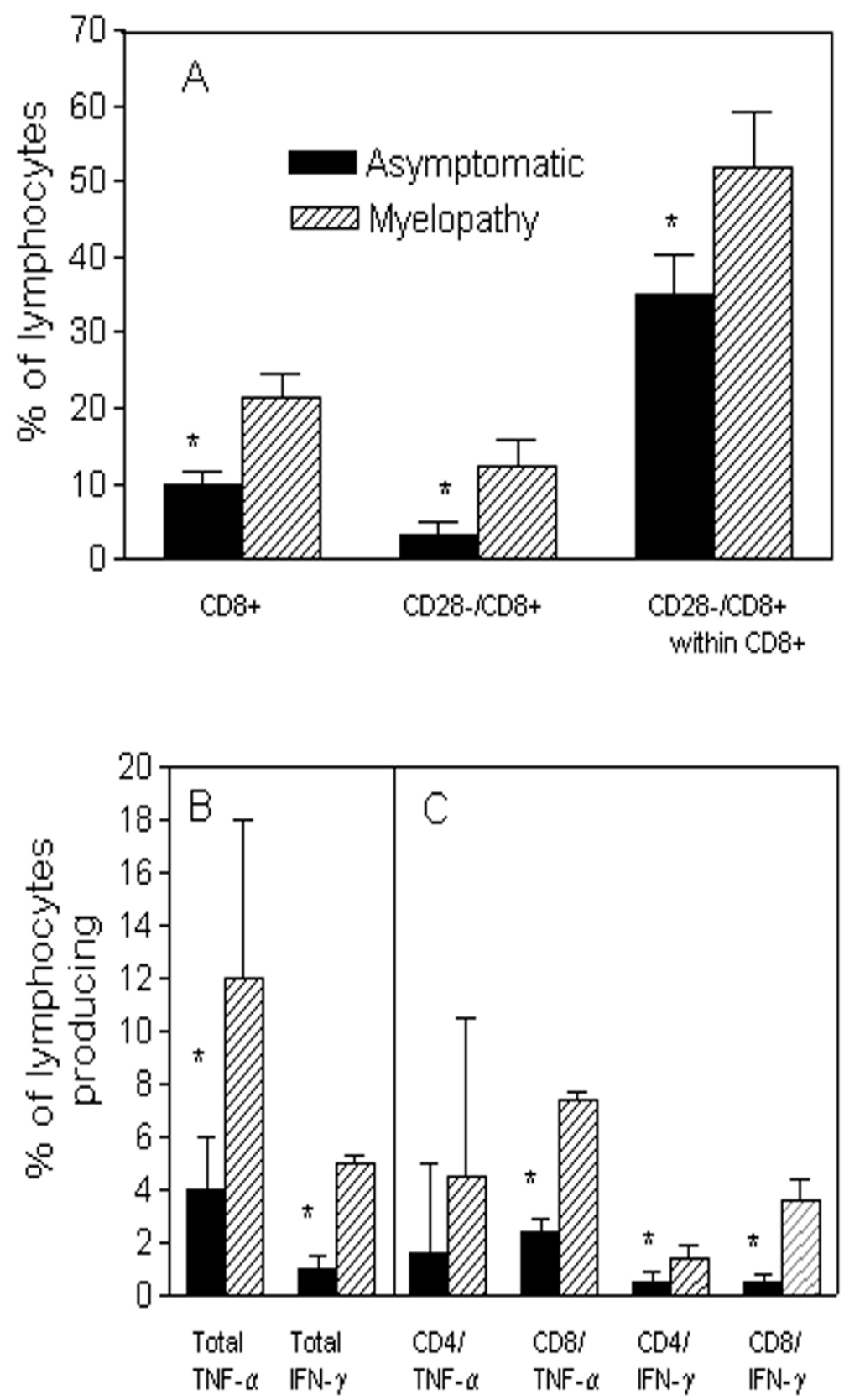

Figure 3

HAM/TSP patients display a higher frequency of CD28-/CD8+ T cells and inflammatory cytokine producing T cells than do asymptomatic carriers. PBMC from 4 HAM/TSP and 8 asymptomatic carriers were analyzed ex vivo or following a 20 hour media alone culture for the expression of CD4+ and CD8+ T cell subpopulations using flow cytometry. Figure $3 A$ shows the frequency of CD8 cells and the subpopulations defined by CD28 expression. Figure 3B shows the frequency of total lymphocytes producing TNF- $\alpha$ and IFN- $\gamma$. Figure $3 C$ shows the relative contribution of CD4+ or CD8+ T cells to the overall cytokine producing population shown in Figure 3B. The data represent the mean \pm S.D and the asterisk represents differences with a $p<0.05$ (MannWhitney U Test). 
Evaluation of immunological responses in patients with HAM/TSP and asymptomatic carries is important for the understanding of the pathogenesis of the HAM/TSP, and to identify early immunological markers associated with progression from infection to disease. This study indicates a higher and significant spontaneous lymphoproliferation and IFN- $\gamma$ production in HAM/TSP patients as compared to HTLV-I asymptomatic carriers. Additionally, lymphocyte responses were quite variable, and in some asymptomatic carriers the lymphocyte proliferation and IFN- $\gamma$ production were similar to those found in patients with myelopathy. These data induce us to observe if the parameters could be considered good markers of disease progression. This is in agreement with our previous observations that asymptomatic carriers can be divided in high and low producers according to IFN- $\gamma$ levels [22]. A great variability of immune response observed in about $40 \%$ of HTLV-I infected subjects was not reflecting a temporary situation, since the IFN- $\gamma$ levels were relatively constant within an individual over time (eight months). During this period of time no neurological manifestation was documented and no other disease that could alter the immune response was observed.

Many studies have demonstrated that IFN- $\gamma$ and TNF- $\alpha$ produced in large quantities contribute to tissue damage of the central nervous system $[23,24]$, and are likely involved in the pathogenesis of several infections and non-infections disease. The flow cytometric determination of cytokine producing lymphocytes extend the observations made in supernatants of lymphocytes cultures showing a significant increase in the frequency of IFN- $\gamma$ and TNF- $\alpha$ producing cells in patients with HAM/TSP. This difference was accounted for both CD4+ and CD8+ T cells for the TNF- $\alpha$ producing cells, and mainly by CD8+ $\mathrm{T}$ cells for IFN $\gamma$ producing lymphocytes. Since CD4+ T cells are the main source of IFN- $\gamma$ in HTLV-I carriers $[22,25,26]$ this data may indicate that during the evolution from asymptomatic to myelopathy there is a switch from $\mathrm{CD} 4+$ to $\mathrm{CD} 8+$ in relation to the main cell producing IFN- $\gamma$. These findings support studies suggesting that CD8+ T cells may play an important role in the pathogenesis of HAM/TSP [27].

Previous studies have shown that CD28-/CD8+ cells display high cytotoxic activity, playing an important role in the pathology associated with viral diseases $[28,29]$. Additionally, recent studies have shown that HIV-1 can incorporate $\mathrm{CD} 28$ and the acquisition of this specific host surface glycoprotein modulates the virus life cycle [30]. Moreover, the role of CD28-/CD8+ T cells in HAM/TSP needs to be further investigated since these cells may induce cell damage and / or death in infections disease [31].
In conclusion, these results show an exacerbated type 1 immune response in HAM/TSP patients, characterized by elevated IFN- $\gamma$ production, an increased frequency of TNF$\alpha$ and IFN $-\gamma$ producing lymphocytes, and by an increase in the frequency of CD28-/CD8+ T cells. Given that cellular activation and pro-inflammatory cytokine production are likely directly involved in the pathogenesis of HAM/TSP disease, longitudinal studies of HTLV-I infected asymptomatic carriers who present with high lymphoproliferative response, high production of IFN- $\gamma$ and TNF- $\alpha$ and high expression of CD28-/CD8 + T cells should be conducted to determine the frequency of disease progression in this group. The identification of markers of HAM/TSP progression will allow for earlier initiation of current therapeutic interventions, and hopefully delay the fast and progressive development of the motor disability observed in HTLV-I infected individuals.

\section{Competing interests}

None declared.

\section{Authors' contributions}

SBS carried out the immunological studies, performed statistical analysis and drafted the manuscript. ALM, EM and AM participated in the coordination of neurological evaluations. AFP was involved in clinical evaluation of the patients. ARJ participated in the design and statistical analysis. WOD and KJG carried out FACS analysis and EMC conceived the study and participated in its design and coordination.

\section{Acknowledgment}

This study was supported by the Brazilian Research Council (CNPq) and Fundação de Apoio à Pesquisa do Estado da Bahia (FAPESB). Dr. Edgar M. Carvalho is a senior investigator. We thank the members of STS (Serviço de Transfusão de Sangue - Salvador - Ba) and HEMOBA (Hemocentro da Bahia) by guiding the blood donors with HTLV positive serology. We also thank Elbe Myrtes Souza Silva for her technical assistance in preparing this manuscript.

\section{References}

I. Galvao-Castro B, Loures L, Rodriques LG, Sereno A, Ferreira Junior OC, Franco LG, Muller M, Sampaio DA, Santana A, Passos LM et al.: Distribution of human T-lymphotropic virus type I among blood donors: a nationwide Brazilian study. Transfusion 1997, 37:242-243.

2. Moreira ED Jr, Ribeiro TT, Swanson P, Sampaio Filho C, Melo A, Brites C, Badaro R, Toedter G, Lee H, Harrington W Jr: Seroepidemiology of human T-cell lymphotropic virus type I/II in northeastern Brazil. J Acquir Immune Defic Syndr 1993, 6:959-963.

3. Uchiyama T, Yodoi J, Sagawa K, Takatsuki K, Uchino H: Adult T-cell leukemia: clinical and hematologic features of 16 cases. Blood 1977, 50:48I-492.

4. Poiesz BJ, Ruscetti FW, Gazdar AF, Bunn PA, Minna JD, Gallo RC: Detection and isolation of type $C$ retrovirus particles from fresh and cultured lymphocytes of a patient with cutaneous T-cell lymphoma. Proc Natl Acad Sci U S A 1980, 77:74I5-74I9.

5. Gessain A, Barin F, Vernant JC, Gout O, Maurs L, Calender A, de The G: Antibodies to human T-lymphotropic virus type-I in patients with tropical spastic paraparesis. Lancet 1985, 2:407-4I0. 
6. Osame M, Usuku K, Izumo S, ljichi N, Amitani H, Igata A, Matsumoto M, Tara M: HTLV-I associated myelopathy, a new clinical entity. Lancet 1986, I:1031-1032.

7. Prince H, Kleinman S, Doyle M, Lee H, Swanson P: Spontaneous lymphocyte proliferation in vitro characterizes both HTLVI and HTLV-II infection. J Acquir Immune Defic Syndr 1990, 3:1199-1200.

8. Kubota R, Kawanishi T, Matsubara H, Manns A, Jacobson S: Demonstration of human T lymphotropic virus type I (HTLV-I) taxspecific CD8+ lymphocytes directly in peripheral blood of HTLV-I-associated myelopathy/tropical spastic paraparesis patients by intracellular cytokine detection. J Immunol 1998, I 6 1:482-488.

9. Nishimoto N, Yoshizaki K, Eiraku N, Machigashira K, Tagoh H, Ogata A, Kuritani T, Osame M, Kishimoto T: Elevated levels of interleukin-6 in serum and cerebrospinal fluid of HTLV-I-associated myelopathy/tropical spastic paraparesis. J Neurol Sci I990, 97:183-193.

10. Osame M: Pathological mechanisms of human T-cell lymphotropic virus type I-associated myelopathy (HAM/TSP). J Neurovirol 2002, 8:359-364.

II. Jacobson S, Gupta A, Mattson D, Mingioli E, McFarlin DE: Immunological studies in tropical spastic paraparesis. Ann Neurol 1990, 27:149-156.

12. Jacobson S: Cellular immune responses to HTLV-I: immunopathogenic role in HTLV-I-associated neurologic disease. J Acquir Immune Defic Syndr Hum Retrovirol 1996, I 3:SI 00- 106.

13. Taylor GP, Tosswill JH, Matutes E, Daenke S, Hall S, Bain BJ, Davis R, Thomas D, Rossor M, Bangham CR et al.: Prospective study of HTLV-I infection in an initially asymptomatic cohort. J Acquir Immune Defic Syndr 1999, 22:92-100.

14. Izumo S, Goto I, Itoyama Y, Okajima T, Watanabe S, Kuroda Y, Araki S, Mori M, Nagataki S, Matsukura S et al.: Interferon-alpha is effective in HTLV-I-associated myelopathy: a multicenter, randomized, double-blind, controlled trial. Neurology 1996, 46:1016-1021.

15. Kurtzke JF: Rating neurologic impairment in multiple sclerosis: an expanded disability status scale (EDSS). Neurology 1983, 33:|444-|452.

16. Kramer A, Maloney EM, Morgan OS, Rodgers-Johnson P, Manns A, Murphy EL, Larsen S, Cranston B, Murphy J, Benichou J et al.: Risk factors and cofactors for human $T$-cell lymphotropic virus type I (HTLV-I)-associated myelopathy/tropical spastic paraparesis (HAM/TSP) in Jamaica. Am $J$ Epidemiol 1995, 142: $1212-1220$

17. Nagai M, Usuku K, Matsumoto W, Kodama D, Takenouchi N, Moritoyo T, Hashiguchi S, Ichinose M, Bangham CR, Izumo $S$ et al.: Analysis of HTLV-I proviral load in 202 HAM/TSP patients and 243 asymptomatic HTLV-I carriers: high proviral load strongly predisposes to HAM/TSP. J Neurovirol I998, 4:586-593.

18. Hanon E, Hall S, Taylor GP, Saito M, Davis R, Tanaka Y, Usuku K, Osame M, Weber JN, Bangham CR: Abundant tax protein expression in CD4+ $T$ cells infected with human $T$-cell lymphotropic virus type I (HTLV-I) is prevented by cytotoxic T lymphocytes. Blood 2000, 95: I386-I392.

19. Azimi N, Mariner J, Jacobson S, A WT: How Does Interleukin I5 Contribute to the Pathogenesis of HTLV Type I - Associated Myelopathy/Tropical Spastic paraparesis? AIDS Research and Human Retroviruses 2000, I6:17|7-1722.

20. Kubota R, Kawanishi T, Matsubara H, Manns A, Jacobson S: HTLV-I specific IFN-gamma+ CD8+ lymphocytes correlate with the proviral load in peripheral blood of infected individuals. J Neuroimmunol 2000, 102:208-215.

21. Nagai M, Jacobson S: Immunopathogenesis of human $T$ cell lymphotropic virus type I-associated myelopathy. Curr Opin Neurol 2001, 14:381-386.

22. Carvalho EM, Bacellar O, Porto AF, Braga S, Galvao-Castro B, Neva $\mathrm{F}$ : Cytokine profile and immunomodulation in asymptomatic human T-lymphotropic virus type I-infected blood donors. J Acquir Immune Defic Syndr 200I, 27: I-6.

23. Umehara F, Izumo S, Ronquillo AT, Matsumuro K, Sato E, Osame M: Cytokine expression in the spinal cord lesions in HTLV-Iassociated myelopathy. J Neuropathol Exp Neurol 1994, 53:72-77.

24. Biddison WE, Kubota R, Kawanishi T, Taub DD, Cruikshank WW, Center DM, Connor EW, Utz U, Jacobson S: Human T cell leukemia virus type I (HTLV-I)-specific CD8+ CTL clones from patients with HTLV-I-associated neurologic disease secrete proinflammatory cytokines, chemokines, and matrix metalloproteinase. J Immunol 1997, I 59:2018-2025.

25. Richardson JH, Edwards AJ, Cruickshank JK, Rudge P, Dalgleish AG: In vivo cellular tropism of human $\mathrm{T}$-cell leukemia virus type I. J Virol 1990, 64:5682-5687.

26. Popovic M, Lange-Wantzin G, Sarin PS, Mann D, Gallo RC: Transformation of human umbilical cord blood $T$ cells by human $T$. cell leukemia/lymphoma virus. Proc Natl Acad Sci U S A 1983, 80:5402-5406.

27. Sakai JA, Nagai M, Brennan MB, Mora CA, Jacobson S: In vitro spontaneous lymphoproliferation in patients with human $\mathrm{T}$-cell lymphotropic virus type I-associated neurologic disease: predominant expansion of CD8+ T cells. Blood 200I, 98: I 506-I5I I.

28. Azuma M, Phillips JH, LL L: CD28- T lymphocytes. Antigenic and functional properties. J Immunol 1993, I 50(4): I I 47- I I59.

29. Weekes MP, Wills MR, Mynard K, Hicks R, Sissins JG, AJ C: Large clonal expansions of human virus-specific memory cytotoxic T lymphocytes within the CD28- CD8+ T-cell population. Immunology 1999, 98(3):443-449.

30. Giguere JF, Paquette JS, Bounou S, Cantin R, MJ T: New insight into the functionality of a virion-anchored host cell membrane protein: CD28 versus HIV type I. J Immunol 2002, I 69(5):2762-277I.

31. Dutra WO, Martins-Filho OA, Cancado JR, Pinto-Dias JC, Brener Z, Gazzinelli G, Carvalho JF, Colley DG: Chagasic patients lack CD28 expression on many of their circulating $T$ lymphocytes. Scand J Immunol 1996, 43:88-93.

\section{Pre-publication history}

The pre-publication history for this paper can be accessed here:

http://www.biomedcentral.com/1471-2334/4/7/prepub

Publish with Bio Med Central and every scientist can read your work free of charge

"BioMed Central will be the most significant development for disseminating the results of biomedical research in our lifetime. "

Sir Paul Nurse, Cancer Research UK

Your research papers will be:

- available free of charge to the entire biomedical community

- peer reviewed and published immediately upon acceptance

- cited in PubMed and archived on PubMed Central

- yours - you keep the copyright

Submit your manuscript here:

http://www.biomedcentral.com/info/publishing_adv.asp

BioMedcentral 